\title{
The Contribution of Social Support and Religious History on Religious Conversion: A Quantitative Study in South Tangerang
}

\author{
Rochimah Imawati \\ Faculty of Da'wah and Communication \\ Syarif Hidayatullah State Islamic University Jakarta \\ E-mail: rochimah.imawati@uinjkt.ac.id
}

\begin{abstract}
Changing in religious comprehension and behaviour called Religious Conversion. External Religious Conversion is movement from a religion which is followed by an individual to another religion, whereas internal Religious Conversion is changing in religious behaviour in the same religion to become better or the contrast, become worse. Phenomenon in the last few years, there many Religious Conversion in some Indonesian moslem people. From many factors affect the changing, the writer intended to describe the contribution of Social Support and Religious History of the follower of religion towards Religious Conversion. The writer supported by previous study using quantitative method with respondent from moslem domiciled in South Tangerang area. For the afterward study, other variables with bigger amount of sample is expected.
\end{abstract}

Keyword: Religious Conversion, Social Support, and Religious History

\section{INTRODUCTION}

Since the purification spirit of religion has revealed, the religious movement (hijrah) among religious followers has found its own momentum. In the study of religious psychology the term of hijrah is a form of religious conversion, namely the internal conversion of religion. Based on researches undertaken by [1], and [2], the changes in the religion become a phenomenon. Those researches focused on social studies. Another research done by [3], and [4] focused on inter-religious movement. Related to previous research, the author is interested to look specifically at the subject of religious conversion, based on how the social support and religious history contribute to that conversion.

The author chose the research location in Tangerang Selatan as Tangerang Selatan is a city with the center of Islamic propagation studies that developed rapidly on the recent year. That phenomenon gives impact on religious conversion in a person, especially for adolescence to adulthood. Moreover, some State and
Private Universities, Public or Islamic are located in Tangerang Selatan. That factor has an impact with the way of religious thinking especially on the adolescent and adulthood period. The phenomenon of Hijrah itself, was interpreted differently among religious people. It becomes a trend among teenagers; it is understood symbolically among adulthood. Those phenomenon has been interpreted by instant religious transformation. The interpretation based on role of social support for religious conversion; How the contribution of a religious history related to religious conversion.

According to identification of the problem, the researcher limits the research on how social support and religious histories contribute to religious conversion in Tangerang Selatan. The purpose of the research is to identify on the contribution of social support and religious history contribute to religious conversion in Tangerang Selatan.

\section{LITERATURE REVIEW}

\section{A. Religious Conversion}

Religion is a belief that concerns the inner side of a person related to the value of life. For humans, value is something principle that considered true. Actualization of values as a view of life will appear in its attitude and behavior. Then conversion of religion is generally interpreted as a change in religion. William James[5] gave the classic definition to which subsequent writers have repeatedly returned to be converted, to be regenerated, to receive grace, to experience religion, to gain assurance, are so many phrases which denote the process, gradual or sudden, by which a self hitherto divided, and consciously wrong, inferior and unhappy, becomes unified and consciously right, superior and happy, in consequence of its firmer hold upon religious realities. Paloutzian[6] Conversion is defined as a more 
distinct process by which a person goes from believing, adhering to, and/ or practicing one set of religious teachings or spiritual values to believing, adhering to, and/ or practicing a different set. The transformative process in conversion may take variable amounts of time, ranging from a few moments to several years, but it is the distinctiveness of change that is its central identifying element. In contrast to someone arriving at a point of belief through the process of socialization and other developmental mechanisms, the convert can identify a time before which the religion was not accepted and after it was accepted. Religious Conversion concerns with soul matter and the social influence. In this matter, it means the external factor that is movement from one religion into another religion. Whereas change internal factor means change to be better in perceiving and implementing religious doctrines (shaleh), or the contrary (fasik). Those the characteristics have something in common that is a change in direction of one's views and beliefs towards his religion. Changes that occur are affected based on psychological condition in which changes can occur suddenly or through a process. The symptoms of that change are not always the same in each person or group. In volitional type or gradual change type, this conversion is a process of struggling to become better religious adherent. The other type is self-surrender or drastic change, in which a person or group in his or her religion changes rapidly, naturally accepting the new condition with complete surrender of the soul. William James in his book The Varieties of Religious Experience and Max Heirich in his book Change of Heart divides the factors of conversion of religions into three categories, and one other factor[7]. First: according to religious scholars, religious conversion occurs because of divine guidance. Super Natural influences play a dominant role in the process of conversion of religion to a person or group. Secondly: according to Sociologists, conversion occurs because of social influence. The social environment includes: interpersonal relationships; involvement with religious activities both religious and non-religious; regular, traditional, or cultural practices prevailing in the surrounding community; invitation from the closest people are: family, relatives, friends, or groups; influence of religious leaders; the influence of social networks; and the influence of the state authorities. Where such influences can be persuasive or coercive. Third: according to the
Psychologist, conversion is a result of a strong mental force and influences the emergence of new perceptions, becoming a solid idea. It can also happen because of a psychological crisis resulting from the existence of a very profound life event. Psychological influence in religious conversion consists of internal factors and external factors. Internal factors are from within the person itself: personality and nature, while the external is: family, neighborhood, status change, and poverty (economic problems). Lastly, according to Education experts, religious conversion is also influenced by the conditions of education. Religious education materials, the atmosphere of religious and general education, and the existence of religious education institutions, greatly affect the understanding and religious behavior.

\section{B. Social Support}

Nan Lin [8] explains: Support defines as an act or process that promotes assist, or hold up something else. Social support denotes forces or factors that sustain human beings. Accordingly, social support can be defined as the forces or factors in the social environment that the survival of human beings. Yet although this definition may be adequate in general discourse, it certainly not specific enough for research purposes. This is the definition of social relations and interaction that is relevant to physical and mental health. Social support is a physical and psychological comfort given by others such as family, relatives, or friends. This support can be a form of encouragement or help to face problems, traumatic events, environmental adaptations and life change[9]. Smet [10] explains that the first source of social support is from the closest people in someone's life (e.g. spouse, nuclear family, and close friends); secondly is from the people of social networks over a period of time (e.g. colleagues, social groups); the third is from influential people or groups (e.g. religious leaders, counselors, professionals, distant relatives, etc.). The operational definition in this research is consistent of what is stated by Gottlieb, social support consists of verbal and / or nonverbal information or advice, concrete assistance, or action provided by social intimacy, or acquired by the presence of those who has an emotional or behavioral benefit to the recipient. While the aspects of social support are described in Smet namely: emotional, award, instrumental, and informative support. 


\section{Religious History}

The religious life of a person is represented in his attitude and behavior as a result of what and how religion is acquired during the period of growth and development throughout his life. Every phase of human life has different stages, followed by the level of age, cognitive ability, psychological appreciation, and behavior learned from the environment and education. Referred to a method of research of religious psychology, as a personal document of the subject of research, in this research the history of religion is also used and assumed as a variable that contribute to someone's religion in the next level [11]

\section{METHODS}

The method used in this research is descriptive correlational method by using quantitative approach of multiple linear correlation analysis[12]. The research that describes the contribution of social support and religious history to religious conversion. This study discusses three variables; two independent variables and one dependent variable. The independent variable is the variable that influences or causes the change or the incidence of the dependent variable. Dependent variable is the variable that affected the result of the independent variables. In this study the independent variables (X1) are Social Support, and the Religious History (X2), while the dependent variable (Y) is the Religious Conversion.

The relationship between variables $\mathrm{X} 1, \mathrm{X} 2$ and $\mathrm{Y}$ are described in the following table:

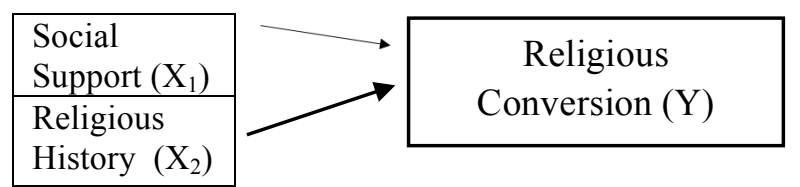

H1: The contribution of Social Support (X1) to Religious Conversion (Y)

$\mathrm{H} 2$ : The contribution of Religious History (X2) to

Religious Conversion (Y)

H3: The contribution of Social Support (X1) and Religious History (X2) to Religious Conversion (Y)

\section{Population and Sample}

The population in this study is the Muslim community living in Tangerang Selatan, while the sample is taken using the technique of Purposive sampling. Purposive sampling technique was applied because the selection of a group of subjects is based on certain characteristics that are considered to have a close connection with the characteristics of the population that has been known before, in other words the sample units contacted according to certain criteria applied based on the purpose of research. The number of sample taken is 40 samples.

Research Instruments was designed in accordance with the theoretical review. The Instrument is the designed questions in the form of Likert Scale of questionnaire. The questions are based on theories. In Social Support, as independent variable (X1) consists of 20 items, independent variable (X2) consists of 20 items, and Dependent Variable that is Religious History (Y) consists of 20 items, so the whole statement is 60 items.

\section{Research Finding and Discussion}

Profile of this respondent aims to find out the characteristics of selected Muslims to be respondents. This section describes the results of the research obtained from the distribution of questionnaires to the sample. Data obtained from the spread of this questionnaire is the primary data of research conducted. The dissemination of the questionnaires applied the technique of Purposive sampling.

\section{The Respondent Profiles}

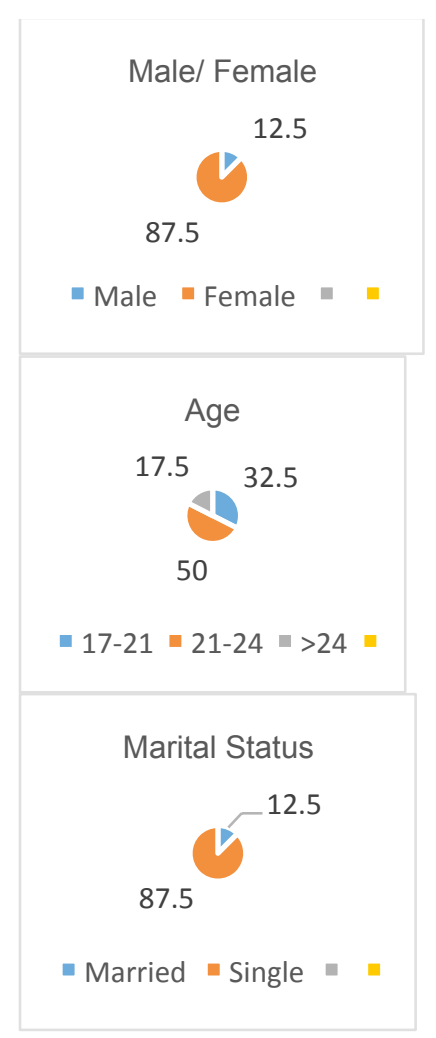



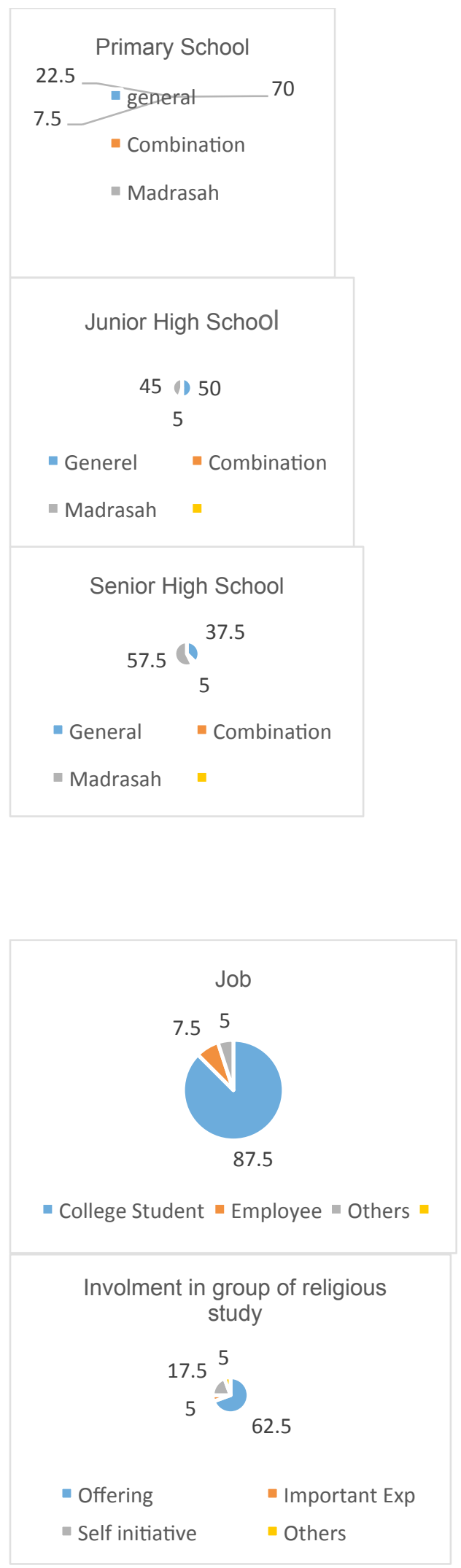

The description of research finding from each of the research variables; Social Support Contribution (X1),
Religious History (X2) and Religious Conversion (Y) Quantitative Study in Tangerang Selatan, are described in the following data description section:

\section{Social Support Variables (X1) Religious history (X2) and Religious Conversion (Y) of Quantitative Studies in Tangerang Selatan}

Social Support Variables (X1) and Religious History (X2) are one independent variable, while Religious Conversion $(\mathrm{Y})$ variable is dependent variable. The researcher distributed questionnaires to 40 respondents, in which 20 instruments for Social Support, 20 instruments for Religious History, and 20 instruments for Religious Conversion. The questionnaires are distributed to Muslims who experienced religious conversion Tangerang Selatan.

\section{Validity Test}

Validity test of Social Support Variable Instruments (X1). Based on the above table, by

$\mathrm{n}=40$ and $5 \%$ significant level then it is obtained the table value for $n=40$ of 0.3120 . So to see the result in the validity test table instrument of Social Support variable (X1), if the result is positive and $r$ table value is greater than $\mathrm{r}$ table 0.3120, then the instrument of social support variable (X1), based on the above table, it is obtained the results of 19 instruments are valid, and 1 instrument is invalid, so the outline of the research instrument is valid.

Validity Test Religious history (X2). Based on the above table, with $\mathrm{n}=40$ and $5 \%$ significant level then obtained $r$ table value for $n=40$ of 0.3120 . So to see the result of $r$ count Religious history (X2), obtained value of rcount is positive and greater than $r$ table 0.3120 , then the variable instrument Religious history (X2), based on the above table obtained the results of 19 instruments are valid, and 1 instrument is invalid, so the outline of the research instrument is valid.

Test the Validity of Religious Conversion (Y2). Based on the above table, with $\mathrm{n}=40$ and $5 \%$ significant level then obtained $\mathrm{r}$ table value for $\mathrm{n}=40$ of 0.3120 . So to see the result of $r$ count the test table of validity of instrument of Conversion Religion variable (Y), if the obtained positive rcount value and bigger than $\mathrm{r}$ table 0,3120 , then the instrument of variable of Conversion of Religion (Y), based on table above obtained result 19 instruments are valid, and 1 instrument is invalid, so the outline of the research instrument is valid.

\section{Reliability Test}

Reliability Test on Instrument Variable Social Support (X1). Based on the above table, the results obtained by the reliability test of Social Support variable (X1) with the value of $r$ table 0.3120 , and the value of Alpha reached the 0.920, it can be 
concluded that $\mathrm{r}$ Alpha positive and larger than $r$ table that is $0.920>0.3120$, it can be assumed that research instrument on Social Support variable (X1) is reliable.

Instrument Reliability Test Variable Religious History (X2). Based on the above table, we can get the result of reliability test of variable of Religious History (X2) with rtable value 0.3120 , and result of Alpha value equals to 0.927 , it can be concluded that rAlpha is positive and bigger than rtable that is $0.927>0.3120$, it can be assumed that research instrument on Religious (X2) History is reliable.

Reliability Test Instrument Variable Conversion Religion (Y). Based on the above table, the results obtained reliability test variable Religion Conversion with rtable value 0.3120 , and the value of Alpha amounted to 0.930 , it can be concluded that rAlpha positive and larger than the rtable ie $0.930>0.3120$, it can be assumed that research instrument on Conversion Religion (Y) is reliable.

\section{HYPOTHESIS}

Relationship between Social Support (X1) and Religious Conversion (Y). The correlation value for $\mathrm{X} 1$ (Social Support) with Y (Religious Conversion) is 0.457 , and the effect is in the medium category, while the rtable value for $\mathrm{n}=40$ is 0.312 , or it can be seen $0.312,0.312$, so it can be concluded that partially Social Support variable X1 has a positive relationship with Religious Conversion (Y), $\mathrm{H} 0$ is rejected and $\mathrm{Ha}$ accepted, besides the relationship between Social Support (X1) and Religious Conversion (Y) is significant because the probability value is less than 0.05 .

Relation between Religious History (X2) and Religious Conversion (Y). If the result of the correlations table above shows, the correlation value of rcount for X2 (Religious History) with Y (Religious Conversion) is 0.570 , and the influence is included in medium category, while the rtable value for $\mathrm{n}=40$ is 0.312 , or can be seen $0.52>0.312$, so it can be concluded that the partial variable of Religious History (X1) has a positive relationship with Religious Conversion (Y), $\mathrm{H} 0$ is rejected and $\mathrm{Ha}$ accepted, besides the relation between Religious History (X2) and Religious Conversion (Y) is significant because the probability value is less than 0.05 .

\section{AnovaTest}

\begin{tabular}{|c|c|c|c|c|c|}
\hline Model & $\begin{array}{l}\text { Sum of } \\
\text { Squares }\end{array}$ & Df & Mean Square & $\mathrm{F}$ & Sig. \\
\hline Regression & 1654.105 & 2 & 827.052 & 14.191 & $.000^{\mathrm{a}}$ \\
\hline Residual & 2156.295 & 37 & 58.278 & & \\
\hline Total & 3810.400 & 39 & & & \\
\hline
\end{tabular}

a. Predictors: (Constant), Religious History $\left(\mathrm{X}_{2}\right)$, Social Support $\left(\mathrm{X}_{1}\right)$

b. Dependent Variable: Religion Conversion (Y)

From the Anova test/ ftest / fcount it is obtained the value of 14.191 which is bigger than ftable of 3.9, ie 14.191> 3.9 with a significant level of 0.000 , because $0.000<0.05$, it can be stated that Social Support variables (X1) and Religious History (X2) collectively relate to the Conversion of Religion (Y).

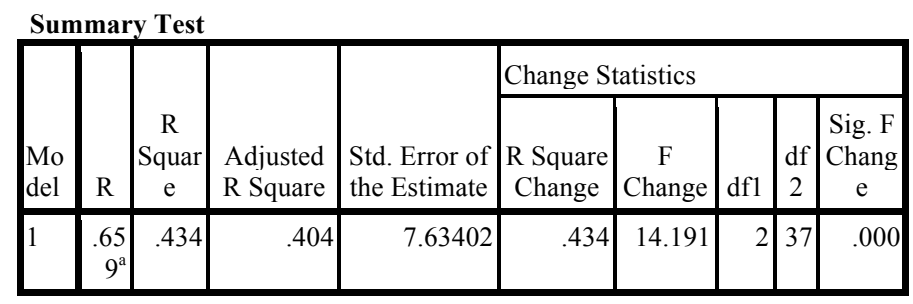

a. Predictors: (Constant), Social Support (X1), Religious History (X2)

Based on the Summary model which yields $\mathrm{R}$ value of 0.659 , and larger with rtable that is $0.659>0.312$, it shows that Social Support (X1) and Religious History (X2) contribute strongly to Religious Conversion (Y), with a percentage of $43 \%$, so that $57 \%$ Religious Conversion that influenced by other factors are not investigated in this research.

\section{CONCLUSION}

Changes in religious behavior, or it is called Hijrah, becomes a phenomenon in society. Hijrah in Religious psychology is a part of the internal religion conversion. This religious phenomenon becomes interesting because it looks quite conspicuous in group activity and the appearance of certain symbols. The movement of hijrah is slowly but surely extends to various social circles, as well as the age level. Individually it is important to see how a person in a past or contemporary religion contributes to religious conversion. On social support, variables comes from family, relatives or friends, and friends in the group become the most important variable in the conversion process of religion. Religious history, on the other hand, is intended to find on how the someone's religion is influenced by conditions and activities happened at home, educational institutions, and the environment.

The results showed that the contribution of social support and religious history affected to religious conversion. Each factor has a positive relationship, in which each variable has moderate force to a religious 
conversion. Powerful force to a religious conversion can happen if those variables are combined. Both variables contribute $43 \%$ to religious conversion is explained in this research.

This research is a previous limited study of religious conversion, in the terms of the number of respondents. For further research, it is suggested to use or add other variables that can be used as dependent variable on religious conversion, such as from the educational background, social status, economy, and others; or the other way around where religious conversion is used as an independent variable in religious phenomenon with larger and varied respondents.

\section{REFERENCES}

[1] Mariambang, "Fenomena Keberagamaan Mahasiswa Muslim Pada Perguruan Tinggi Agama Dan Umum Di Kota Medan," IAIN - Medan, vol. Vol 1 No.3.

[2] F. Pattilouw, "Fenomena Keberagamaan Di Indonesia," IAIN Ambon, vol. Vol 5 No.1.

[3] Z. Pontoh and M. Farid, "Hubungan antara Religiusitas dan Dukungan Sosial Dengan kebahagiaan Pelaku Konversi Agama," UnTag - Surabaya, vol. Vol.4 No.01, 2015.
[4] R. R. Kusuma and E. Zulaifah, "Kuputuskan Menjadi Muslim.".

[5] E. H. Feurgeson, "The Definition Of Religious Conversion," Pastoral Psychology, vol. Volume 16, no. Issue 6, p. pp 8-16, Sep. 1965.

[6] N. Kok, "Religious Conversion Compared." Leiden University Repisitory, 08-Aug-2016.

[7] Jalalaluddin, Psikologi Agama, 16th ed. Jakarta: Grafindo, 2012.

[8] L. Song, J. Son, and N. Lin, "Social Support," in The Sage Handbook of Social Work Analysis, London, 2011, pp. 116-128.

[9] R. A. Baron and N. R. Branscombe, Social Psychology. New Jersey: Pearson, 2012.

[10] B. Smet, Psikologi Kesehatan, 1st ed. Jakarta: Grasindo, 1994.

[11] L. K. George, "Religious/ Spiritual History," Fetzer Inst., no. Multidimensioanl Measurement of Religiousness/ Spirituality for Use in Health Research, p. 65, 2003.

[12] F. N. Kerlinger, Asas-asas Penelitian Behavioral, 3rd ed. Jogjakarta: UGM Press, 1990. 